\title{
Environmental conditions and paleowind directions at the end of the Weichselian Late Pleniglacial recorded in aeolian sediments and geomorphology (Twente, Eastern Netherlands)
}

\author{
Ko (J.) van Huissteden ${ }^{1,2}$, Jacques C.G. Schwan ${ }^{3}$ \& Mark D. Bateman ${ }^{4}$ \\ 1 Vrije Universiteit, Faculty of Earth Sciences, De Boelelaan 1085, 1081 HV Amsterdam, \\ The Netherlands \\ 2 corresponding author; e-mail \\ ${ }^{3}$ Mauritsstraat 35, 3583 HH Utrecht, The Netherlands \\ 4 Sheffield Centre for International Drylands Research, Department of Geography, \\ Winter St., University of Sheffield Sheffield S10 2TN Great Britain
}

Manuscript received: September 2000; accepted in March 2001

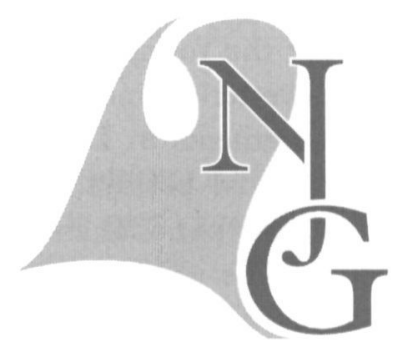

\begin{abstract}
The Late Weichselian Pleniglacial wind regime in the eastern Netherlands is reconstructed by means of landform and sedimentological analysis. This analysis involves aeolian and fluvial landforms in the Dinkel river valley in the Twente region. The aeolian deposits considered here date from the Last Glacial Maximum (approximately $22 \mathrm{ka}$ ) to the start of the Bølling Interstadial at $14.7 \mathrm{ka}$.

A major event in this period is the formation of a cryoturbation level caused by permafrost degradation, overlain by an erosional hiatus dated between 21 and $17 \mathrm{ka}$. Both features are attributed to a period of warmer and moister climate, causing permafrost degradation and erosion by surficial runoff. Thereafter aeolian activity prevailed under relatively arid conditions. A deflation surface was formed, the Beuningen Gravel Bed. This deflation surface is present in many Weichselian sections in the Netherlands and the adjacent parts of Belgium and Germany. The deflation occurred concurrently with deposition of coversand at other places.

The morphology of the coversand-landscape in the Dinkel valley was controlled by the relief of the pre-existing floodplain and the wind pattern. Coversand ridges consisting of low dunes accumulated near the margins of the active channel belt. Relatively thick sand sheets occur in the leesides of the ridges, thin sand sheets are found at greater distance.

Mainly westerly sand-transporting winds operated during winter and summer. In winter aeolian deposition occurred by frequent and strong easterly winds also. On the smallest, local scale, the pattern of deposition was determined by the topography and moisture of the receiving surface.

Coversand deposition came to an end with the formation of a sand sheet under relatively warm and less arid conditions. Coversand deposition continued into the Bølling Interstadial; colonization of the coversand surface by vegetation probably has been delayed by nutrient-poor conditions.
\end{abstract}

Keywords: aeolian features, periglacial features, palaeoclimate, Weichselian, Last Glacial Maximum, Netherlands.

\section{Introduction}

During the Weichselian Late Pleniglacial/Marine Isotope Stage 2 aeolian deposition occurred over large areas in the European lowlands bordering the ice sheet (Catt, 1977; Schwan, 1986, 1988; Koster, 1988; Kozarski \& Nowaczyk, 1991; Kasse, 1997). Abundant sources of unconsolidated sediments, a sparse vegetation and a subdued relief favoured the development of an extensive aeolian sand belt (Kasse, 1997). The term 'coversands' is often used because the deposits tend to cover the underlying topography as a continuous mantle.

Systematic studies of sedimentary environment of the coversands were published by Ruegg (1983), Schwan (1986, 1987, 1988). Most of these deposits have originated as sand sheets (Schwan, 1988), in particular at the transition from the Pleniglacial to the Late Glacial (Kasse, 1997). Horizontal lamination or low angle cross-lamination prevails in the structure of 
the sand sheets whilst bedding attributable to dune slip face progradation is very rare. Positive relief forms probably are restricted to hummocks or dome dunes (Schwan, 1988; Kasse, 1997). Following Kasse (1997), the predominance of sand sheets relates to a high ratio between wind energy and sand availability.

Evidence with respect to the wind regime during deposition of the coversands is scarce, and palaeowind directions cannot be deduced from dune shape since clearly oriented dune forms are generally lacking. Based on dune orientation in the Younger Coversands, Maarleveld (1960) inferred wind directions varying from WNW during the Older Dryas to WSW during the Younger Dryas. Schwan (1989) obtained northwesterly wind directions from grain orientation measurements in Late Glacial and Late Pleniglacial coversands; besides unimodal orientation distributions, also bimodal and polymodal distributions were found. The areal distribution of coversand and loess which represents a downwind sediment fining pattern indicates a northerly provenance of the aeolian sediment. Schwan (1986) proposed a fluctuating wind regime, with strong, sand transporting winds during winter, and calmer conditions favouring settling of fines from suspension during the summer. This is based on the often distinct alternation of coarser and finer layers in the coversands.

The age of the sand sheet deposits is uncertain. In general, dateable organic matter is found only in the Late Glacial deposits, but not in the sand sheets which were laid down during the Late Pleniglacial. Normally these units, and the underlying fluvial strata, lack organic material so that the establishment of a more precise chronology has been impossible hitherto (Van Huissteden, 1990). Previous attempts in thermo-luminescence (TL) dating (Dijkmans \& Wintle, 1991) have failed, yielding ages that are too young. Recent age determinations using the optically stimulated luminescence (OSL) method yielded results that conform to the existing radiocarbon chronology of over- and underlying units (Bateman \& Van Huissteden, 1990; Bateman et al., in prep).

Despite the featureless terrain of most coversand areas, some show a more varied topography, for example the Twente region in the eastern Netherlands (Fig. 1), the type area for the coversand stratigraphy (Van der Hammen, 1951; Van der Hammen \& Wijmstra, 1971; Doppert et al., 1975; Van Huissteden, 1990).

In particular the floodplain of the Dinkel river shows a large variety of aeolian landforms dating from the Late Pleniglacial and the Late Glacial. The coversands belong to the Twente Formation which comprises aeolian and fluvial depoits of local origin (Fig.

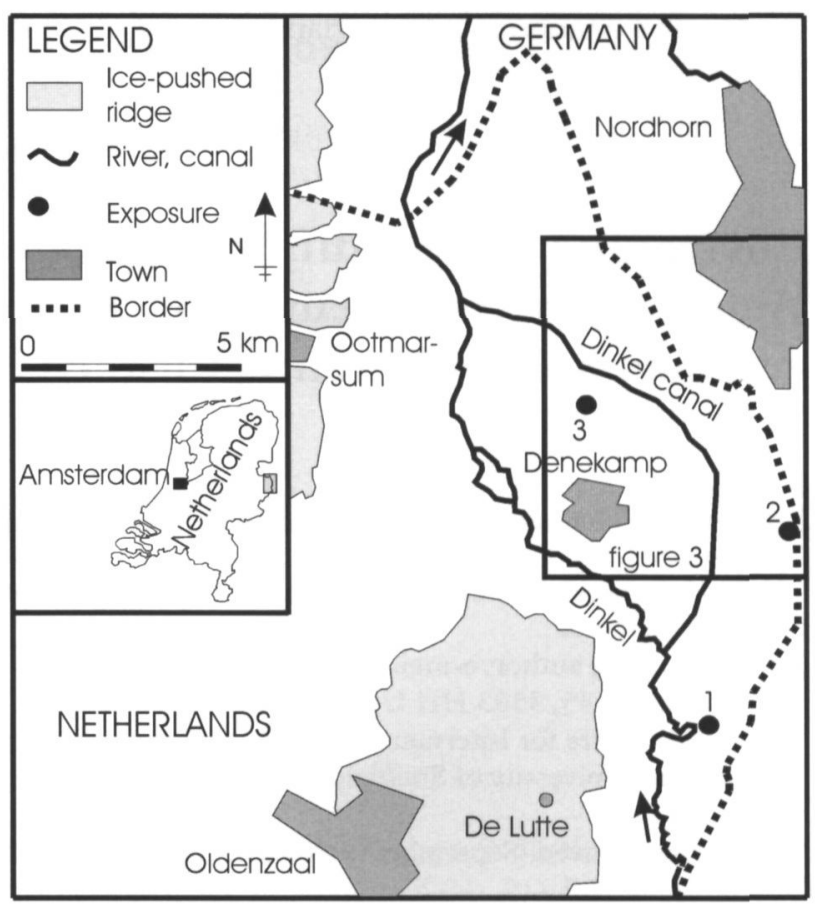

Fig. 1. Location of the study area and studied sites, including the geomorphological map area of fig. 3. Exposures: 1: Lutterzand; 2: Vrijdijk; 3: Nicolaasstichting.

2). The main coversand units in this formation are the Beverborg Member (fluvio-aeolian deposits, including the Older coversands I of Van der Hammen \& Wijmstra, 1971), the Lutterzand Member (also known as Older Coversands II), and the Wierden Member (the Younger Coversands of Late Glacial age). An important stratigraphical marker is the 'Beuningen Gravel Bed' (BGB), an erosion surface overlain by a deflation lag. It truncates a level of large cryoturbations.

Morphological and sedimentological data from this area in combination with an OSL-based chronology, permit reconstruction of the climate and environmental changes during the Late Pleniglacial. The time frame of this study starts at the maximum cold of the Last Glacial Maximum (LGM) at approximately 24 kyr (24,000 year), and lasts until the start of the Bølling Interstadial (ca. 14.7 kyr, Björck et al., 1998) when sand sheet sedimentation was gradually replaced by soil formation and localized dune formation (Kasse, 1997). The oldest date on organic deposits interfingering with coversand is $12,930 \AA 210$ ${ }^{14} \mathrm{C}$ yrs (14,692 cal BP) by Van Geel et al. (1989). We concentrate on the coversand sedimentation postdating the cryoturbation phase below the BGB (Fig 2), dated as younger than ca. $22 \mathrm{kyr}$.

Two sites have been investigated in detail: the Lutterzand site, a permanent river bank exposure which is the stratotype of the coversands (Van der Hammen \& Wijmstra, 1971), and a small sand pit (Vrijdijk) on 


\begin{tabular}{|c|c|c|c|c|c|}
\hline \multirow{2}{*}{$\begin{array}{l}\text { CHRONO- } \\
\text { STRATIGRAHY }\end{array}$} & \multicolumn{4}{|c|}{ LITHOSTRATIGRAPHY } & \multirow{2}{*}{ FACIES } \\
\hline & \multicolumn{3}{|c|}{ van der Hammen, 1971} & $\begin{array}{l}\text { This paper, } \\
\text { Van Huissteden, } 1990\end{array}$ & \\
\hline 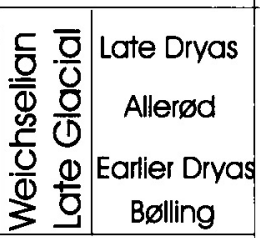 & \multirow{4}{*}{ 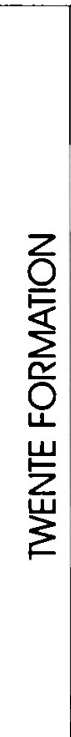 } & $\begin{array}{l}\text { Wierden } \\
\text { Member }\end{array}$ & $\begin{array}{c}\text { Younger } \\
\text { Coversand II } \\
\text { Usselo } \\
\text { Soil } \\
\text { Younger } \\
\text { Coversand I }\end{array}$ & $\begin{array}{l}\text { Wierden } \\
\text { Member }\end{array}$ & \multirow{3}{*}{$\begin{array}{l}\text { Aeolian dunes with cross- } \\
\text { bedding and sandy texture } \\
\text { Aeolian sand sheets and low } \\
\text { dunes with mainly horizontally } \\
\text { bedding and grain size ranging } \\
\text { between silt and coarse sand }\end{array}$} \\
\hline \multirow{3}{*}{$\begin{array}{l}\text { Weichselian } \\
\text { Late } \\
\text { Pleniglacial }\end{array}$} & & \multirow[t]{2}{*}{$\begin{array}{l}\text { Lutterzand } \\
\text { Member }\end{array}$} & $\begin{array}{c}\text { Older } \\
\text { Coversand II }\end{array}$ & $\begin{array}{l}\text { Lutterzand } \\
\text { Member }\end{array}$ & \\
\hline & & & \multicolumn{2}{|c|}{ Beuningen Grovel Bed } & \\
\hline & & & $\begin{array}{c}\text { Older } \\
\text { Coversand I }\end{array}$ & $\begin{array}{l}\text { Beverborg } \\
\text { Member }\end{array}$ & $\begin{array}{l}\text { Succession of (fluvio)-aeolian } \\
\text { sands and cross-bedded } \\
\text { fluvial sands. Large cryoturbatic } \\
\text { involutions at the top of this unit }\end{array}$ \\
\hline
\end{tabular}

Fig. 2. Chrono- and lithostratigraphy of the coversand deposits.

the Dutch-German border a few km north of the Lutterzand. Additonal information is obtained from a small roadside exposure, Nicolaasstichting (Fig. 1).

\section{Coversand geomorphology in the Dinkel valley.}

The Dinkel river is bordered to the west by icepushed ridges of Saalian age and to the east by outcrops of shales and sandstones of Early Cretaceous age. The northern part of the valley is a wide glacial basin, the Nordhorn Basin, in which the Weichselian age deposits attain thicknesses of more than $25 \mathrm{~m}$. On geomorphological maps of the Dinkel valley (Maarleveld, 1971; Kleinsman et al., 1978) four main geomorphological elements can be distinguished on the valley floor: the present river plain, coversand plains, coversand ridges and younger (Holocene) inland dune fields (Fig.3). Based on more recent research in the area (Vandenberghe \& Van Huissteden, 1988; Van Huissteden, 1990), the following genetical interpretation can be assigned to these units.

\section{The coversand plains.}

On the 'coversand plains' the Beuningen Gravel Bed is covered by a thin veneer of coversand or is exposed at the surface (Van der Hammen \& Wijmstra, 1971). Vandenberghe \& Van Huissteden (1988) and Van Huissteden (1990) re-interpreted the sediments underlying the BGB as fluvio-aeolian sediment deposited by a braided river system dating from the LGM.
The fluvio-aeolian sediments have been laid down as overbank sediments of the river, being a mixture of aeolian sand derived from dry channel beds and flood deposits generated during high river stages. These overbank areas had a slightly higher elevation than the active channel belts. Exposures in these locations show an intercalation of fluvio-aeolian overbank sediments and channel deposits, suggesting frequent migration of channel belts. A similar situation is found in modern high arctic river plains subject to strong wind activity (Pissart et al., 1977, Good \& Bryant, 1985, Dijkmans \& Törnqvist, 1991). The 'coversand plains' on the geomorphological maps correspond with these higher areas. The elevation difference between coversand plains and the channel belt is still visible as a terrain step in many locations.

\section{The present river plain.}

To a large extent, the course of the present Dinkel river and its tributaries is inherited from an ancient precursor. The present river plain merely follows the (low-lying) channel belts of the Weichselian Late Pleniglacial river system. Borehole data show that the present river plain only partly originates from fluvial reworking by the Holocene river system. Instead, parts are covered by only a thin veneer of Holocene overbank sediments overlying fluvial deposits of Weichselian Pleniglacial age, whereas locally deep fluvial incisions are found that have been filled in up to the present floodplain level (Van Huissteden, 


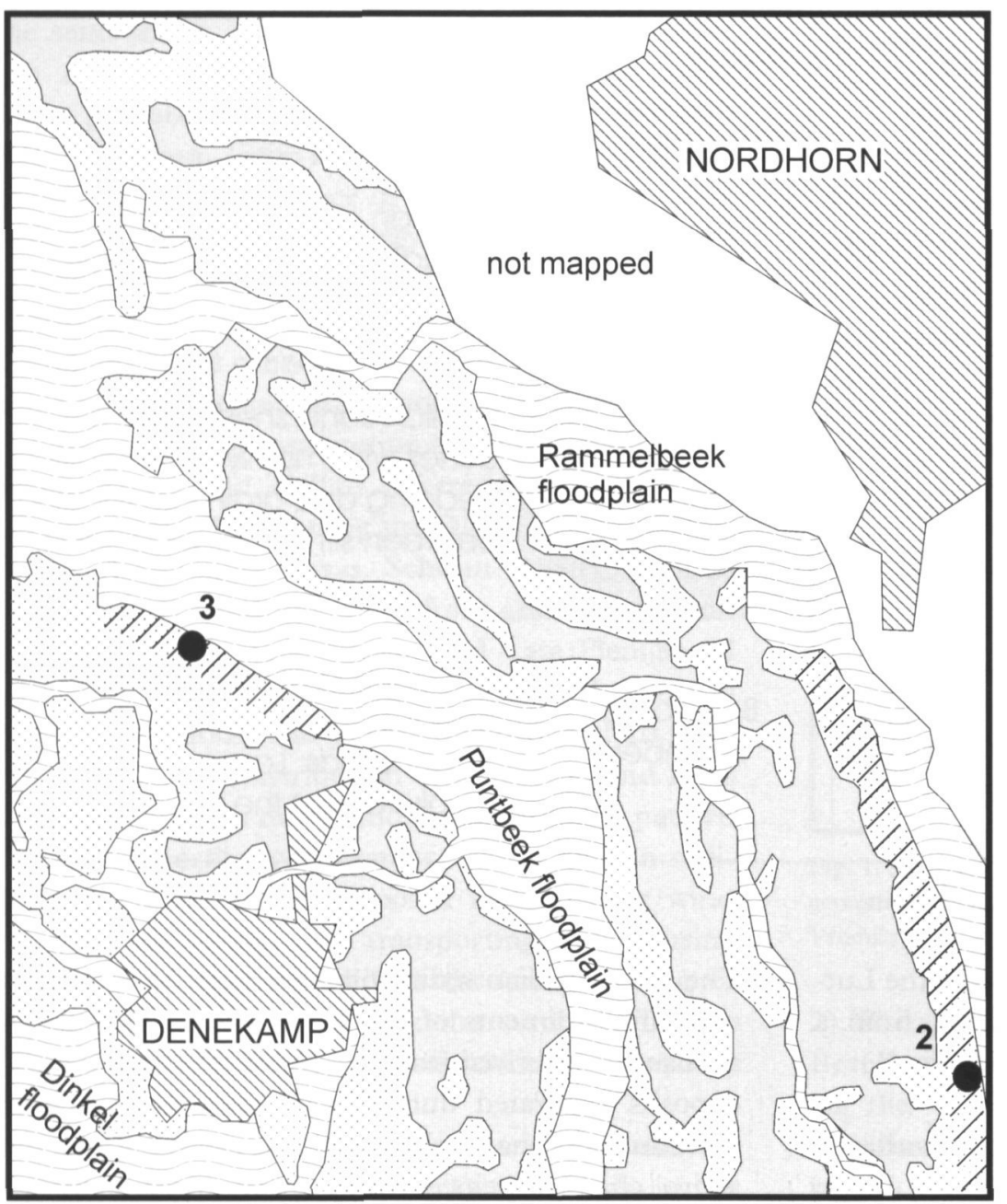

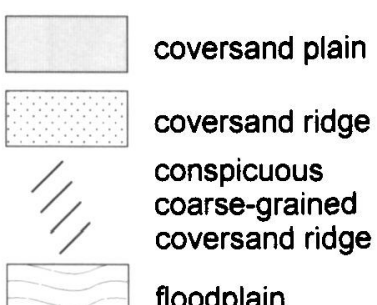

floodplain

exposure

urban area

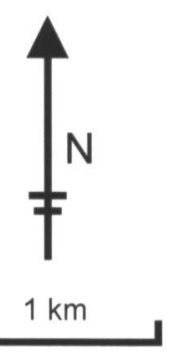

Fig. 3. Geomorphological map of part of the Dinkel valley, showing the relation of morphological features of the coversand deposits with the river floodplain. Redrawn after Kleinsman et al., 1978. 2: Vrijdijk exposure; 3: Nicolaasstichting exposure. The present Dinkel river is located just outside the southwest corner of the map.

1990). The fluvial incisions within the Late Pleniglacial channel belt date from the Late Glacial (probably the Bolling Interstadial) and have subsequently been filled by fluvial sediments of Late Glacial age (Van Huissteden, 1990). We consider the present river plain together with the previous unit as a single complex, representing a now fossil floodplain of Late Pleniglacial age that has been modified only partly by later fluvial activity.

\section{The coversand ridges.}

This landform usually borders the Late Pleniglacial channel belts on both sides (Fig. 3). Like the channel system itself, the ridges have a N-S orientation in the southern part of the valley and NW-SE orientation in its northern part. Two phases of coversand accumulation have formed the ridges (Van der Hammen, 1971; Fig. 4).

The first phase (Lutterzand Member, Figs 2 \& 4) dates from the end of the Late Pleniglacial (Bateman \& Van Huissteden, 1999), after (or contemporaneous with, see below) the formation of the BGB. In general, the relief of the ridges is very subdued (less than 2 $\mathrm{m})$, with very gentle slopes.

The second phase (Wierden Member, Figs 2 \& 4) is of Late Glacial (mostly Late Dryas, 12.6-11.5 ka) age (Van der Hammen, 1971; Bateman \& Van Huissteden, 1999). This unit consists of low dunes (Schwan, 1988). They may overly a soil of Bølling - Allerød age (Van der Hammen, 1971) or directly overly the older coversands. In isolated locations aeolian reworking may have been practically continuous, as is suggested by a Bølling - Allerød soil interfingering with aeolian sand in Fig 4. Dune formation and aeolian reworking during the Late Dryas was generally restricted to already existing coversand ridges, generating localized hummocky dune fields. However, on several locations dunes migrated onto the active floodplain, thereby constricting or damming smaller floodplains (Van der Hammen \& Wijmstra, 1971; Maarleveld, 1971).

\section{The inland dune fields}

These represent landforms generated by aeolian reworking of the coversand ridges after severe land degradation caused by medieval farming practices (Maarleveld, 1971). The dunes have steep slopes and are strongly influenced by the presence of vegetation 


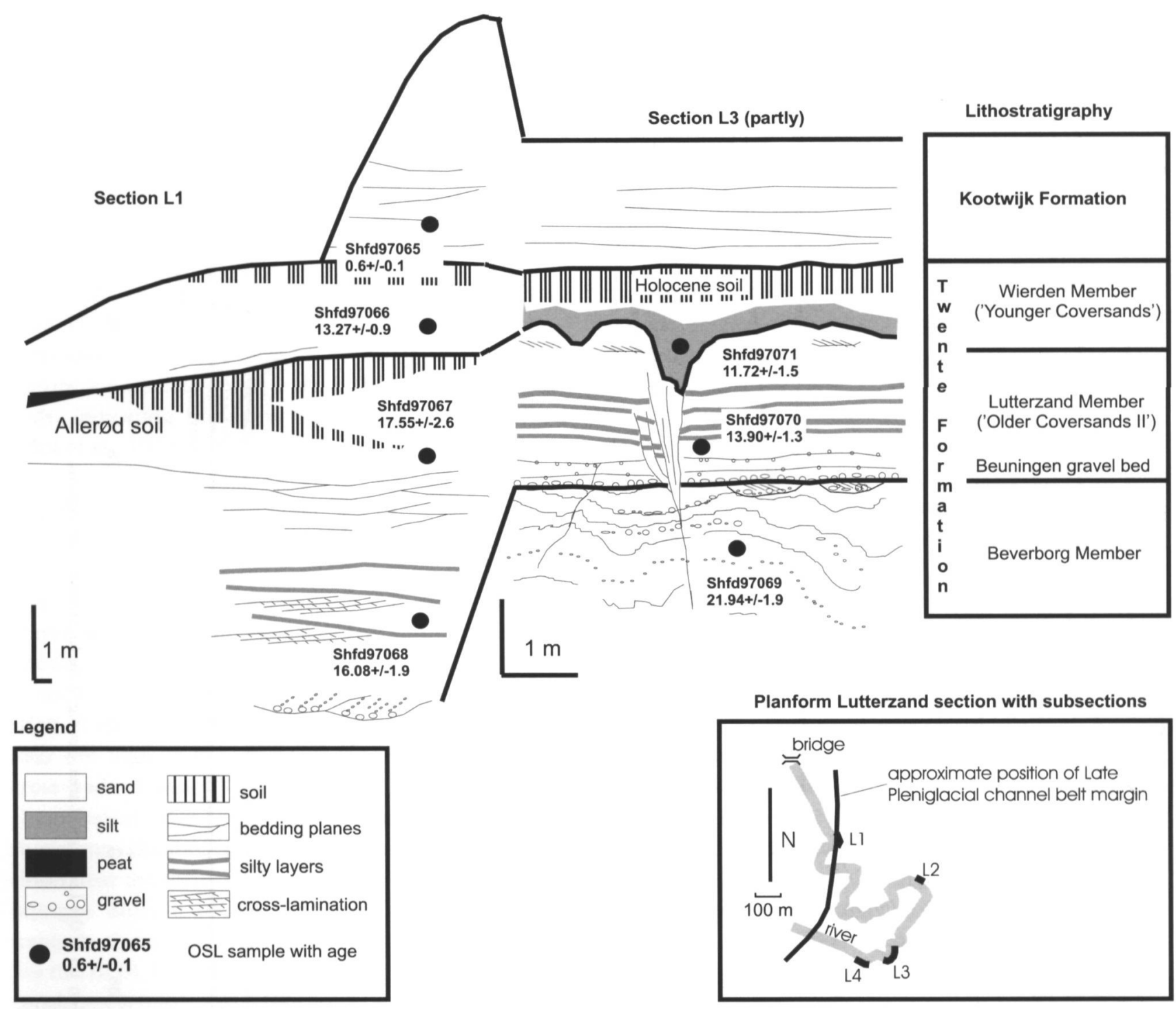

Fig. 4. Synoptic section of the Lutterzand site showing the coversand stratigraphy and the position and ages of the OSL dates, after Bateman \& Van Huissteden, 1999. Lower right: location of subsections in the Lutterzand area.

during their formation. Orientation of individual dunes is inconspicuous, but the Lutterzand inland dune field roughly shows a SE-NW orientation.

\section{Materials and methods.}

The sections described below were studied by means of detailed field sketches of the stratigraphy and sedimentary structures. In the Lutterzand section, the position of subsections relative to each other and the topography of stratigraphical markers was determined using a tachymeter theodolite. Lacquer peels were made at representative sites in the sections using Sigma Coatings CL33 profile varnish. Grainsize analyses were carried out using a Fritsch Analysette 22. laser particle sizer. The samples were pretreated by boiling with $30 \% \mathrm{H}_{2} \mathrm{O}_{2}$ to remove organic material, followed by boiling with $10 \% \mathrm{HCl}$ to remove car- bonate and peptization using a sodium pyrophosphate solution.

\section{Sedimentary features of the Late Pleniglacial coversands.}

\section{Lutterzand section}

In the Lutterzand river-bank exposure a section of $100 \mathrm{~m}$ length has been studied (Fig. 4, 5).

The lithostratigraphy of the section includes the Beverborg, Lutterzand and Wierden Members; the main features of interest are the Beuningen Gravel Bed and the Lutterzand Member. Section Ll is situated at the margin of the active channel belt of the Late Pleniglacial river, the other sections occupy positions at former higher overbank areas. 


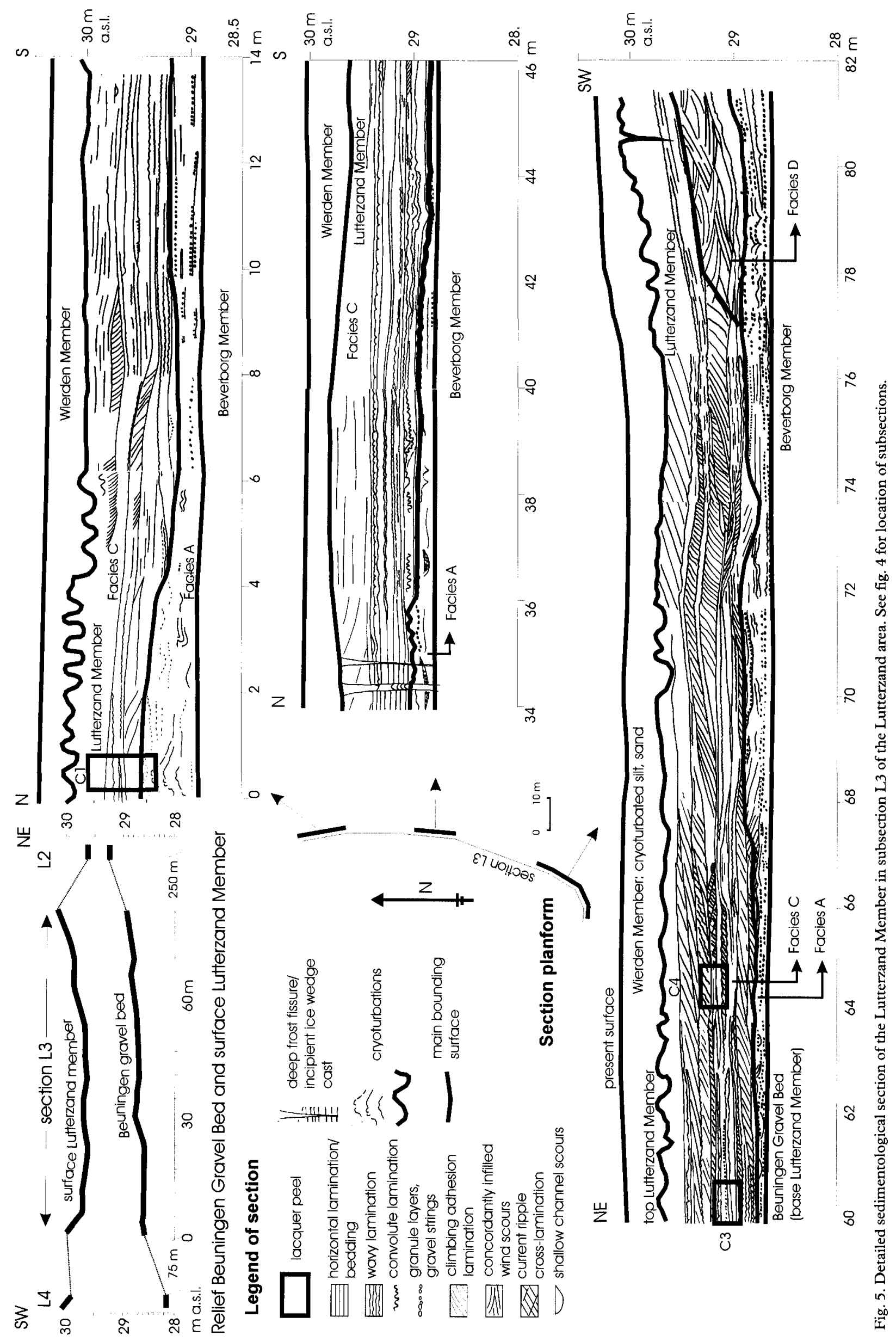


The Beverborg Member.

This is the basal unit, which consists of silty sands intercalated with cross-bedded coarse sands (not depicted in Fig. 5). This complex is of fluvio-aeolian origin, the silty sands represent fluvially reworked aeolian sands and the cross-bedded sands channel deposits. The Beverborg Member is at its top strongly cryoturbated by large amplitude (0.5-0.8 m) cryoturbations. The cryoturbations subsequently have been disturbed by sand-filled frost cracks or sand veins (Van Huissteden et al., 2000). Both the cryoturbations and cracks are truncated by the BGB. A typical feature is a vertical platy structure of the finer grained beds, indicating the former presence of permafrost (Mol et al., 1993).

\section{The Beuningen Gravel Bed.}

In sections L2 through L4 the BGB is well developed, sloping towards the west in the direction of the present river plain. It consists of one or a few strings of gravel, with clast size rarely exceeding a centimeter. Locally, shallow scours filled with cross-bedded gravel occur at the base of the BGB. In section L1 the BGB in its typical facies is absent (Fig. 4). However, near the base of the section a $20 \mathrm{~cm}$ thick layer of cross-bedded gravel occurs, which is probably a lateral equivalent of the $\mathrm{BGB}$. The elevation of the BGB shows considerable variations, it occurs at a lower position near the former river channel (Fig. 5). The 'Beuningen Soil', a weakly developed arctic soil with fragipan charactistics (Vink \& Sevink, 1971) underlies the BGB. In the section it is recognized by its firm consistency, other macroscopically visible signs of soil formation are absent.

\section{The Lutterzand Member.}

Four lithofacies types have been distinguished to cover the variation in the sedimentary make-up of this unit.

Facies $A$ occurs at the base of the Lutterzand Member in sections L2 and L3 (Fig. 5). It is generally less than $0.5 \mathrm{~m}$ thick, in section L2 it is the only representative of the Lutterzand Member. Compared to the other facies types, the material in facies $\mathrm{A}$ is less wellsorted. It consists of generally coarse sand with thin layers and lenses of granules and fine gravel. Compared to the BGB, these gravel strings are discontinuous and lack the coarser $(>0.5 \mathrm{~cm})$ components that are characteristic for the BGB. Frequently the coarse material is concentrated in small scours. The lenses of granules indicate the transport of quite coarse material at relatively high wind speeds. The deposition of aeolian sand has been interrupted frequently by deflation as is testified by discontinuous gravel strings and wind scours. Also surficial running water occurred, as indicated by small cross-bedded scours. Bedding and lamination of the sand is generally even parallel, resembling climbing translatant strata sensu Hunter (1977).

In places, facies $A$ is disturbed by cryoturbation and small frost fissures (up to a few $\mathrm{cm}$ width). The cryoturbations are discontinuous and of much smaller size than those below the BGB $(<0.3 \mathrm{~m})$. The presence of frost fissures testify of low $(<0 \%)$ mean annual temperatures (e.g. Romanovskii, 1985).

Facies $B$ is found only in section $\mathrm{L} 1$, just above the gravel layer at the base of the section (Fig. 4). It consist of well-sorted sands with distinct climbing current ripple lamination. The well-sorted material suggest that facies B consists of fluvially reworked aeolian sand. The climbing ripple lamination indicates high sediment supply, probably from erosion of aeolian deposits upstream.

Facies $C$ consists of well-sorted fine sands and silty sands (Fig. 6).

It is horizontally bedded, without any significant syndepositional cryogenic disturbance. Sedimentary structures are very well preserved (Fig. 7, table 1). Only at the top this facies is disturbed by cryoturbation and ice-wedge casts probably dating from the Late Dryas (Bateman \& Van Huissteden, 1999). Individual beds show a very diverse internal structure.

The data of table 1 may be fitted in an idealized annual cycle of aeolian sedimentation proposed by

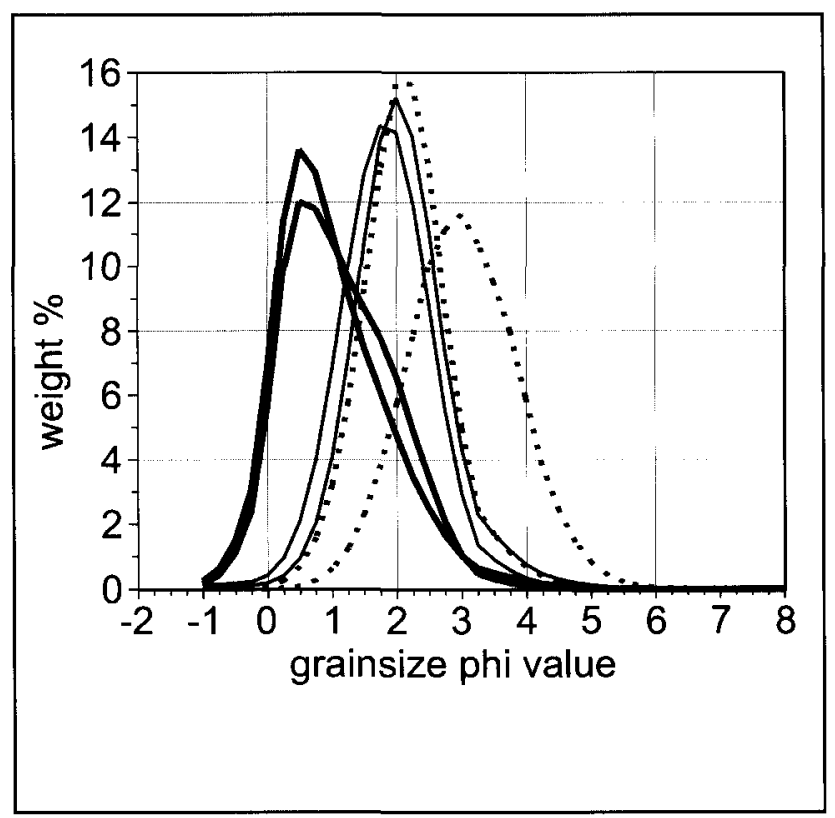

Fig. 6. Representative grainsize distributions of coversand deposits (two for each facies). Thin lines: horizontal parallel laminated sands from facies C; stippled: adhesion ripple sands from facies C (Lutterzand section); thick lines: coarse-grained layers with granules from facies $\mathrm{D}$ (unit $\mathrm{C}$ ) in the Vrijdijk section. 


\begin{tabular}{|c|c|c|c|c|}
\hline \multicolumn{2}{|c|}{ 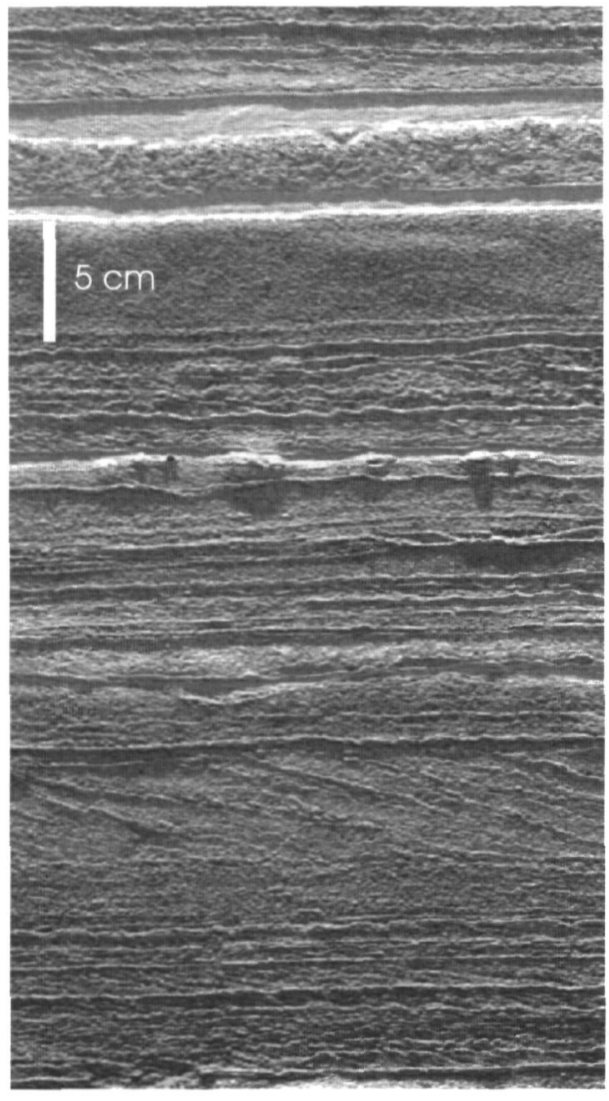 } & $\begin{array}{l}\text { f: detail of lacquer peel } \\
\text { g: detail of lacquer pee } \\
\text { b: structureless silt beds } \\
\text { a structureless sand bed } \\
\text { e: gravel string } \\
\text { h: subhorizontal parallel lc } \\
\text { d: climbing adhesion ripr }\end{array}$ & C1: wave ripple cross & $\begin{array}{l}\text { ination } \\
\text { amination } \\
\text { ams } \\
\text { and }\end{array}$ \\
\hline \multicolumn{5}{|l|}{ lacquer peel C3 } \\
\hline Characteristics & Process & & Literature reference & Stratification type \\
\hline Structureless coarse sand & Niveo-aeolia & deposition & $\begin{array}{l}\text { Washburn, 1979; } \\
\text { Schwan, } 1986\end{array}$ & a \\
\hline Well-sorted, structureless silt & Settling of $w$ & adborne fines from suspension & Schwan, 1986, 1988 & $\mathrm{~b}$ \\
\hline $\begin{array}{l}\text { Crinkly parallel lamination \& } \\
\text { cross-lamination }\end{array}$ & Deposition & a damp surface & Kocurek \& Fielder, 1982 & c \\
\hline $\begin{array}{l}\text { Adhesion ripple pseudo-cross- } \\
\text { lamination }\end{array}$ & $\begin{array}{l}\text { Deposition } \\
\text { Attitude of } c \\
\text { transport dir }\end{array}$ & $\begin{array}{l}\text { a damp surface. } \\
\text { oss-lamination indicates sand } \\
\text { ction }\end{array}$ & Kocurek \& Fielder, 1982 & d \\
\hline $\begin{array}{l}\text { Discontinuos monograin string } \\
\text { of fine gravel }\end{array}$ & $\begin{array}{l}\text { Tractional } \mathrm{p} \\
\text { wind speed }\end{array}$ & icle transport at high & This paper & e \\
\hline Wave-ripple cross-lamination & $\begin{array}{l}\text { Wave rework } \\
\text { of standing }\end{array}$ & $\begin{array}{l}\text { ng in temporary, shallow bodies } \\
\text { ater }\end{array}$ & This paper & $\mathrm{f}$ \\
\hline $\begin{array}{l}\text { Climbing current-ripple } \\
\text { cross-lamination }\end{array}$ & Reworking o & aeolian sand by local current flow & This paper & $\mathrm{g}$ \\
\hline Subhorizontal parallel lamination & $\begin{array}{l}\text { Subritically } \\
\text { from wind } r i\end{array}$ & $\begin{array}{l}\text { mbing translatant strata resulting } \\
\text { le migration }\end{array}$ & Hunter, 1977 & h \\
\hline
\end{tabular}

Schwan (1986). In winter, sand-snow mixtures have been deposited by generally strong winds, producing stratification type $a$ upon melting of the snow. In spring or summer, snow-melt and rainstorms will cause damp surface conditions and even standing water locally. When sand-transporting winds occur coin- 
ciding with these conditions stratification types $c, d$ and $f$ are produced. Localized drainage of the area may be responsible for stratification type $g$. Stratification type $b$ may result from settling of wind-borne fines from suspension during spells of very low wind speed. Stratification type $h$, resulting from wind ripple migration, represents aeolian sedimentation under drier conditions. The grain-size is similar to that of stratification type $c$ and $d$ (Fig. 6).

Stratification type $d$ (adhesion ripple pseudo-crosslamination) is very dominant in parts of the section, especially at the northern and western tips of section L3 (Fig. 5). It is reliable indicator for the palaeo-wind direction (Kocurek \& Fielder, 1982). Although the strike of this delicate lamination is difficult to measure exactly, the combination of section orientation and slope directions in Fig. 5 indicates westerly to northerly winds in combination with the incidence of high soil moisture levels.

Stratification type $e$, a discontinuous gravel string of one grain thick with wind-polished grains up to 5 $\mathrm{mm}$, is a solitary feature. It is difficult to explain by deflation since gravel in the underlying deposit, an erosional surface below the gravel string or indications of gravel transport by current flow are absent. Hence, traction or rolling transport by wind is likely.

In facies $\mathrm{C}$, some indications for the presence of biota (plants and burrowing fauna) have been found, but the vegetation density has been low considering the usually even, undisturbed bed boundaries and lamination. In the Lutterzand section, Facies C everywhere overlies facies A. Syngenetic cryogenic structures are absent in facies $C$.

Facies $D$ is a lateral continuation of facies $\mathrm{A}$ and $\mathrm{C}$ in the part of the exposure closest to the ancient channel belt (Fig. 5). The Lutterzand Member attains greatest thickness and its top is at the highest elevations in sections where facies $\mathrm{D}$ is present. The makeup of the facies is summarized in Table 2 and depicted in Fig. 8.

Facies D supposedly represents a deposit of incipient dome dunes in which slip faces are absent (Schwan, 1988; Kasse, 1997). Deposition in low dunes rather than sheet-wise accumulation is consistent with the over-thickening of the Lutterzand Member where facies D occurs. Stratification type $i$ (Fig. 8), with its prevalence of sub-horizontal lamination, is related to the piling up of dome-shaped bodies of sand. Dune deposits closest to the Pleniglacial channel belt will have suffered from frequent reworking by flood waters. In this setting, formation of stratification type $j$ (Fig. 8) can be expected. Despite the nearness to the channel, the facies $\mathrm{D}$ deposits lack features indicating a damp depositional surface.

Microstructures with lamination dipping in opposing directions, sometimes with a thin vertical core of slightly finer sand (Fig 8) we interpret as features resulting from the presence of a sparse vegetation. The oppositely dipping lamination probably results from leeside sand shadows (Pye \& Tsoar, 1990), the core of the structure may be the trace of the plant stems and roots themselves. Wavy lamination, induced by denser vegetation, (Ruz \& Allard, 1995) is absent.

The top of the Lutterzand Member is overlain by a soil and peat layer in section $\mathrm{L} 1$, in section $\mathrm{L} 3$ and $\mathrm{L} 4$ by a cryoturbated silt bed, belonging to the Wierden Member (Figs. 4, 5). From the same level small icewedge casts penetrate the Lutterzand Member. The soil and peat layer date from the Bølling-Allerød Interstadial (Van der Hammen \& Wijmstra, 1971). The formation of the cryoturbations and ice-wedge casts date from the Younger Dryas stadial (Bateman \& Van Huissteden, 1999). The cryoturbated silt and soil are overlain by coversands of the Wierden Member.

\section{Vrijdijk section.}

The Vrijdijk section is a shallow sand pit in a coversand ridge at the western side of the floodplain of a tributary of the Dinkel river. The elevation difference between the floodplain and the adjacent 'coversand plain' is approximately $1.5 \mathrm{~m}$ and is visible as a clear terrain step, the ridge attains a height of $2.5-3 \mathrm{~m}$ above the coversand plain. Three sedimentary units can be distinguished (Figs. 9 and 10).

Table 2. Stratification types of facies D. Letters in parenthesis in the colum 'Stratification type' refer to examples in Fig. 8.

\begin{tabular}{llc}
\hline Characteristics & Process & Literature reference \\
\hline $\begin{array}{l}\text { Sand beds with subhorizontal, even lamination or } \\
\text { incipient trough cross-bedding. Bed boundaries } \\
\text { with concave-upward shape and intersecting at } \\
\text { low angles. }\end{array}$ & $\begin{array}{l}\text { Scouring and subsequent } \\
\text { infilling by wind. }\end{array}$ & Schwan, 1986, 1988 \\
$\begin{array}{l}\text { Trough cross-bedding in sand. The sand is } \\
\text { distinctly coarser and dip of laminae is steeper than } \\
\text { that of type } i\end{array}$ & $\begin{array}{l}\text { Fluvial reworking of aeolian } \\
\text { sand }\end{array}$ & This paper
\end{tabular}




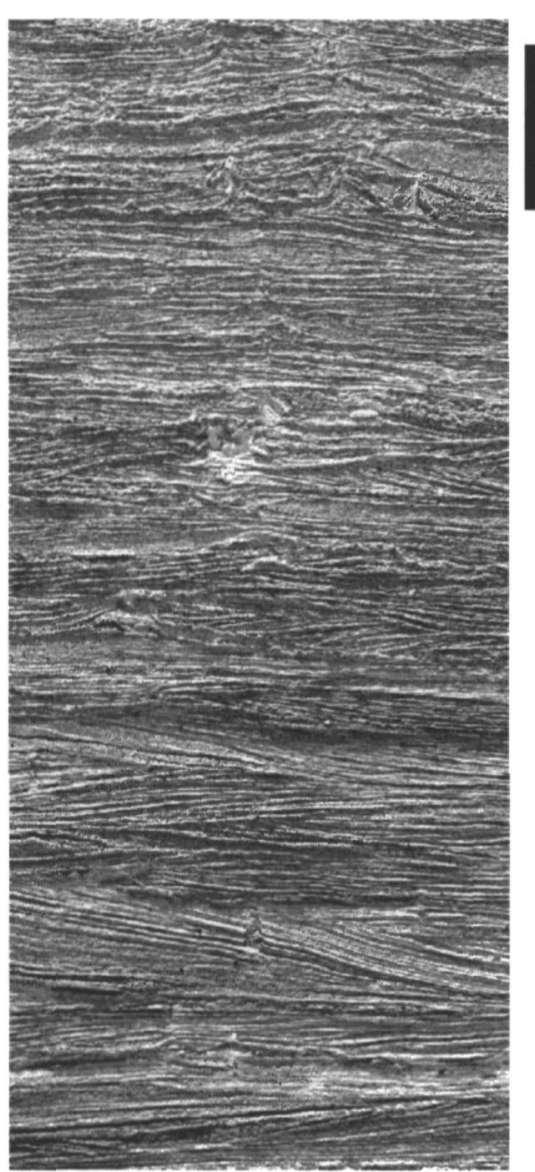

i: subhorizontal even lamination/ low angle cross-bedding
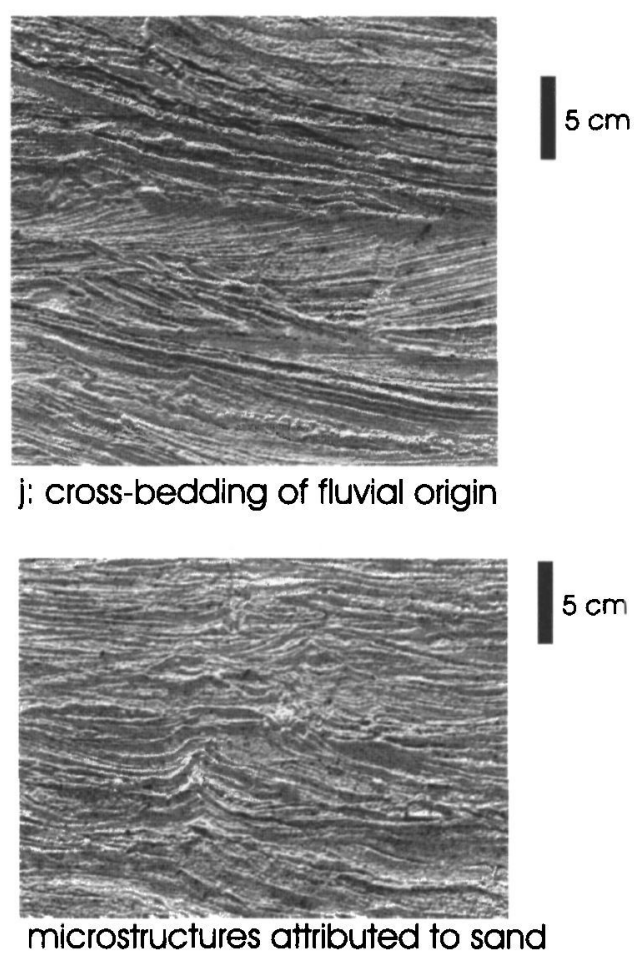

accumulation around plant stems

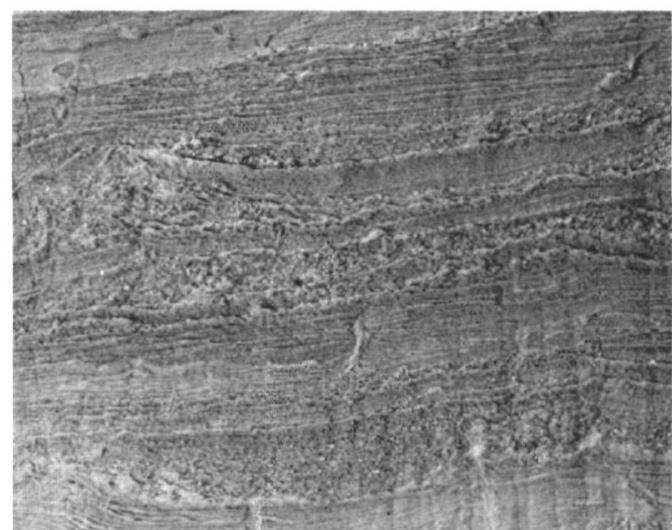

Fig. 8. Details of sedimentary structures in facies D of the Lutterzand Member in the Lutterzand section (section L4) and Nicolaasstichting section (lower right photo, site 3 in fig. 1). Photos from parts of lacquer peels.

Unit $A$.

The basal unit $\mathrm{A}$ is correlative with the Beverborg Member in the Lutterzand. It consists of mediumcoarse sand with large cryoturbations and small frost fissures, similar to the top of the Beverborg Member in the Lutterzand. The upper boundary of the unit is marked by a sharp erosive contact, truncating the cryoturbations. This hiatus is a characteristic part of the BGB although the gravel lag proper is lacking here.

\section{Unit $B$.}

This unit is composed of alternating $\mathrm{cm}$-thick silt and sand beds. The silty strata formed by settling from suspension of windborne fines into shallow ponds. The grain-size of the sand increases towards the top. The parallel lamination in the thicker sand beds at the base resembles adhesion plane bed lamination cf. Kocurek \& Fielder (1982). Because of similarity to stratification type $a$ in the Lutterzand section, the sandy layers may result from (niveo-) aeolian deposition.

The beds show convolute lamination at various scales (Fig 10). The small-scale convoluted lamination indicates water-saturated conditions. However, the larger folds may be related to permafrost melting, continuing after the cryoturbation and truncation of unit $A$. The erosional contact and the lowermost beds of unit $B$ have been disturbed by a small fault, indicating ongoing deformation of the subsoil. The ponding of water at the site may have originated from subsidence due to ground ice thawing, and probably also prevented gravel concentration of the BGB by runoff or deflation. 


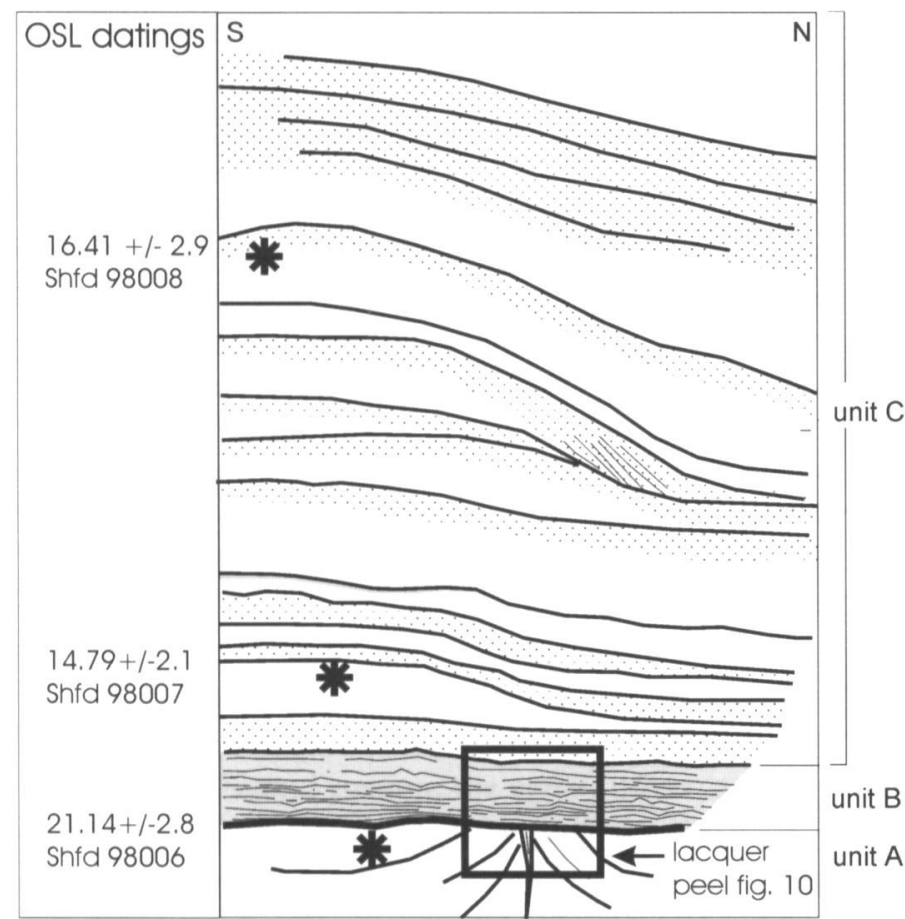

Unit $C$.

In the upper unit, laminae with granule or fine-gravel composition occur regularly in a matrix of medium to coarse sand. This relatively coarse texture and prevalence of inclined bedding and scour-fill cross-bedding are characteristics which this unit shares with facies D in the Lutterzand section. However, unit $C$ is on average distinctly coarser than facies D. Schwan (1988) attributes this type of bedding to dune formation re-
Fig. 9. The Vrijdijk section with OSL dates. After Bateman et al., in prep. Location in fig. 1.

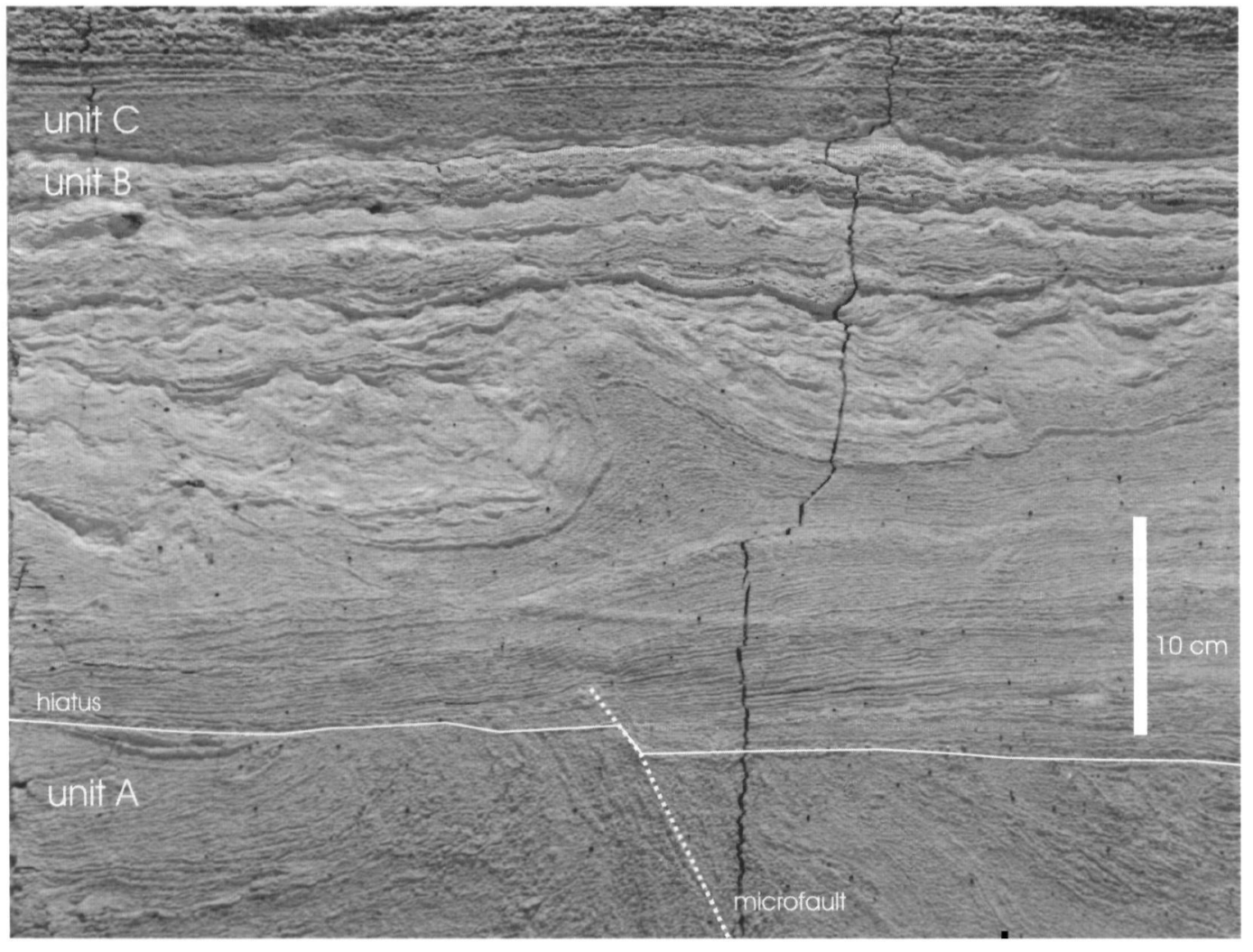

lated to strong winds, suppressing vertical accumulation. Also the abundant coarse grained material indicates high wind stress besides the proximity of a course-grained sand source.

A lacquer peel from a similar site with the same coarse-grained facies shows that the coarsest layers are generally structureless, while intervening finegrained layers exhibit parallel lamination (Nicolaasstichting site, 3 in Fig. 1, 3; Fig. 8). The absence
Fig. 10. Details of the succession of units $A, B$ and $C$ in the Vrijdijk section, showing the hiatus between units $A$ and $B$. Photo from lacquer peel. The vertical crack to the right of the centre of the peel is an artefact caused by peel handling. 


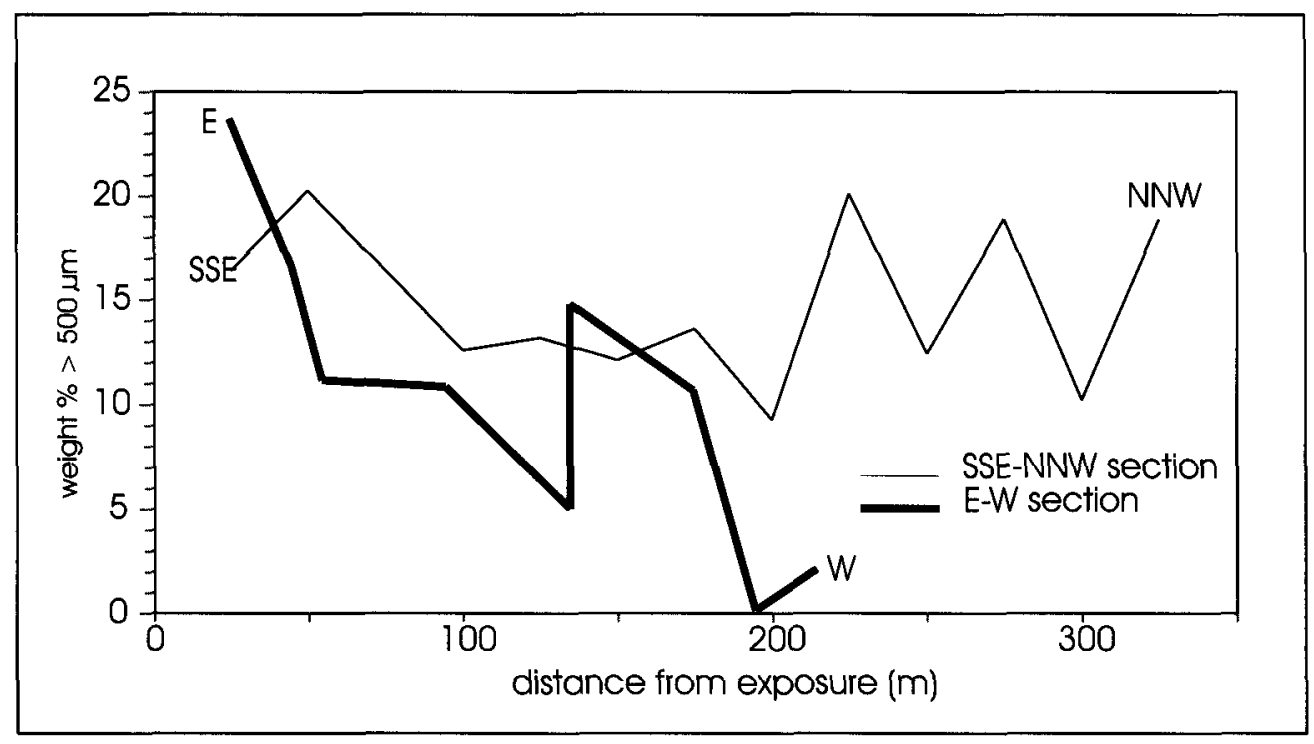

Fig. 11. Trends in the weight percentage of coarse sand fraction (>500 m) in the coversand, sampled from auger hole transects in two different directions in the Vrijdijk dune site. The depth of the samples below the surface is $0.75-1.0$ $\mathrm{m}$.

of lamination indicates a niveo-aeolian origin (Schwan, 1986). Hence it is likely that the coarsest material was transported mainly in winter.

The abundant coarse-grained material indicates a nearby, coarse-grained sand source. To check for a grain size trend within the ridge that may be indicative for transport direction and location of the sand source, the ridge material has been sampled from auger holes at $0.75-1 \mathrm{~m}$ below the present surface, in transects parallel and at right angles to the ridge strike, with a $25-50 \mathrm{~m}$ interval between the auger holes (Fig. 11). The weight percentage of coarse grains $(>500 \mathrm{~m}$ ) rapidly falls of going from east to west. In the transect parallel to the ridge strike this trend is absent.

\section{Discussion.}

\section{Chronology of aeolian erosion/sedimentation.}

The geochronology of the sections is based on OSL dates (Bateman \& Van Huissteden, 1999; Bateman et al., in prep.; Figs. 4,8) and is summarized in table 3.

The ages of the Lutterzand Member range between
17.6 and $13.9 \mathrm{kyr}$ in both sections. The age reversal of the dates in the Lutterzand section and Vrijdijk sections is only apparent, since the dates in question differ less than one standard deviation from each other. The datings and stratigraphic relations suggest that facies $C$ is restricted to the youngest part of the Lutterzand Member. The top of facies $D$ interfingers with $\mathrm{C}$ (Fig. 5). The dating from facies $\mathrm{C}$ (13.9 kyr) is younger than the start of the Bølling Interstadial at $14.7 \mathrm{kyr}$ (Van Geel et al., 1989; Kasse, 1997). Thus, deposition of facies $\mathrm{C}$ (and part of $\mathrm{D}$ ) continued into the Bølling interstadial s.l.

The cryoturbation at the top of the Beverborg Member, formation of the erosional hiatus and the formation of the BGB should be regarded as separate events. First, the cryoturbation level has been formed (Fig. 4, section L3). The large size of the cryoturbations indicates permafrost degradation (Vandenberghe, 1988; French, 1996; Van Huissteden et al., 2000). Next, the hiatus is formed. Usually, this is assumed to be caused by the deflation that also concentrated the BGB (Van der Hammen, 1971). However, at the Vrijdijk section (Figs. 9,10) a clear hiatus is found while an overlying deflation lag is lacking. This

Table 3. OSL datings in ka BP in the Lutterzand and Vrijdijk sections and their relation to sedimentary facies and units. Dating results after Bateman \& Van Huissteden (1999) and Bateman et al., in prep.

\begin{tabular}{|c|c|c|}
\hline \multirow[t]{2}{*}{ Lithostratigraphic } & \multicolumn{2}{|c|}{ Unit Observation site } \\
\hline & Lutterzand section & Vrijdijk section \\
\hline Lutterzand Member & $\begin{array}{c}\text { Facies C: } 13.9 \\
\text { Facies B and D: } 17.6-16.1\end{array}$ & $\begin{array}{l}\text { Unit } C \text { (similar to facies } D \text { in } \\
\text { Lutterzand): } 16.4-14.8\end{array}$ \\
\hline Beuningen Gravel Bed & \multicolumn{2}{|c|}{$21-17$} \\
\hline Beverborg Member & 21.9 & 21.1 \\
\hline
\end{tabular}


demonstrates that at least part of the erosion preceded formation of the BGB deflation lag.

Small gravel filled scours just below the BGB (Fig. 4) suggest that surficial runoff in a dense and shallow channel network has been an important erosion process (Van Huissteden et al., 2000). Vandenberghe \& Kasse, (1993) attribute this type of erosion to cryopediment formation. However, at the same time some channel down-cutting occurred as testified by the coarse channel lag of probably the same age at section L1 of the Lutterzand site. Also Kolstrup (1980) found evidence of channel activity associated with the BGB. This indicates a phase of increased fluvial activity. However, this Late Pleniglacial channel down-cutting is a minor feature compared with the deep fluvial incision that occurred during the Bølling interstadial.

In the Lutterzand section, the age of the cryoturbation level below the BGB and the BGB itself is bracketed between at least $21.9 \mathrm{kyr}$ and $13.9 \mathrm{kyr}$, based on two consecutive dates in one site (Fig. 4). The formation of the cryoturbations and the hiatus occurred between 17 and $21 \mathrm{kyr}$ (table 3). For the formation of the BGB itself, a longer time span is assumed since ages up to $13.9 \mathrm{kyr}$ have been found in sediments just above the BGB.

It is likely that deflation which concentrated the gravel in the BGB occurred patch-wise, while at other favourable sites coversands were deposited at the same time. Deflation has been pronounced on exposed sites, such as the 'coversand plains' or higher areas of the Late Pleniglacial river plain, e.g. in section L2 and L3 at the Lutterzand site (Bateman et al., in prep). Also in other coversand areas of the Netherlands and Belgium, the BGB is particularly well developed on higher areas such as river terraces and interfluves (Vandenberghe, 1985). At the same time, terrain hollows and other favourable sites were subjected to rapid aeolian deposition. Thick accumulations of coversands are found in headwater valleys (Van der Hammen, 1951).

The so-called 'Beuningen Soil' (Vink \& Sevink, 1971) formed during the deflation. The soil formation postdates the cryoturbation, since the intense cryoturbation would have obliterated the fragipan characteristics of the soil. In the Lutterzand section the soil is best developed where the BGB is also a prominent feature. Soil formation is not in contradiction with contemporaneous erosion, if the erosion by deflation has been small as suggested above.

The following sequence of events can be reconstructed for the Late Pleniglacial coversand succession (Fig. 12):

1. During the LGM, deposition of coarse sand in braided river channels on the active channel belt of the river, combined with deposition of finer fluvio-aeolian sands at slightly higher elevations on inactive parts of the floodplain (Fig 12 A; Vandenberghe \& Van Huissteden, 1988; Van Huissteden et al., 2000)

2. Permafrost degradation and formation of large cryoturbations between 21 and $17 \mathrm{kyr}$ (Fig. 12B).

3. Formation of a hiatus by surficial runoff (Van Huissteden et al., 2000), during or shortly after the permafrost degradation, combined with minor channel downcutting (Fig. 12C).

4. Deflation and formation of a desert pavement (the BGB) and the Beuningen Soil, partly contemporaneous with coversand sedimentation. Deposition of facies $\mathrm{D}$ sands as low dunes along the edge of the active floodplain. During high river discharge, these dune sands have been fluvially reworked (facies $B$, intercalations of fluvial cross-bedding in facies $D$ at Lutterzand). At the same time, continued deflation of the BGB, and deposition of facies A sand sheet deposits may have occurred on the higher terrace surfaces. During deposition of facies A, frost processes in the soil were still active, but permafrost did not re-appear (Fig. 12D).

5. Deposition of facies $C$ as a sheet-like sand body under moist conditions, and continued sedimentation of facies D (Fig. 12E).

\section{Areal pattern of distribution of the aeolian sands.}

Combining the aeolian and fluvial morphology in Fig. 3 and the sedimentological data from the sections in the study area, three depositional sub-environments may be distinguished. These are: (i). Ridges forming along the active channel-margin, consisting of low dunes without slipfaces, (ii). Relatively thick sand sheets in the leeside of ridges and (iii). Relatively thin sand sheets alternating with areas of deflation, at greater distance from the ridges.

In the Lutterzand section, the base of the Lutterzand Member shows considerable elevation differences representing terrain steps bordering the ancient braid channel belts (Fig. 5). At the Vrijdijk section, the same can be inferred from the present relief. The greatest mass of the dune ridges is located on the higher side of the terrain slopes bordering the palaeochannel in both the Vrijdijk section and Lutterzand sections. The preferential location of the coversand ridges along the slopes bordering the active channel belts may be attributed to 1) the presence of vegetation, 2) the effect of wind velocity and sand transport rate reduction of these slopes (e.g. Pye $\&$ Tsoar, 1990) and 3) the effects of moisture differences of the receiving surface. 


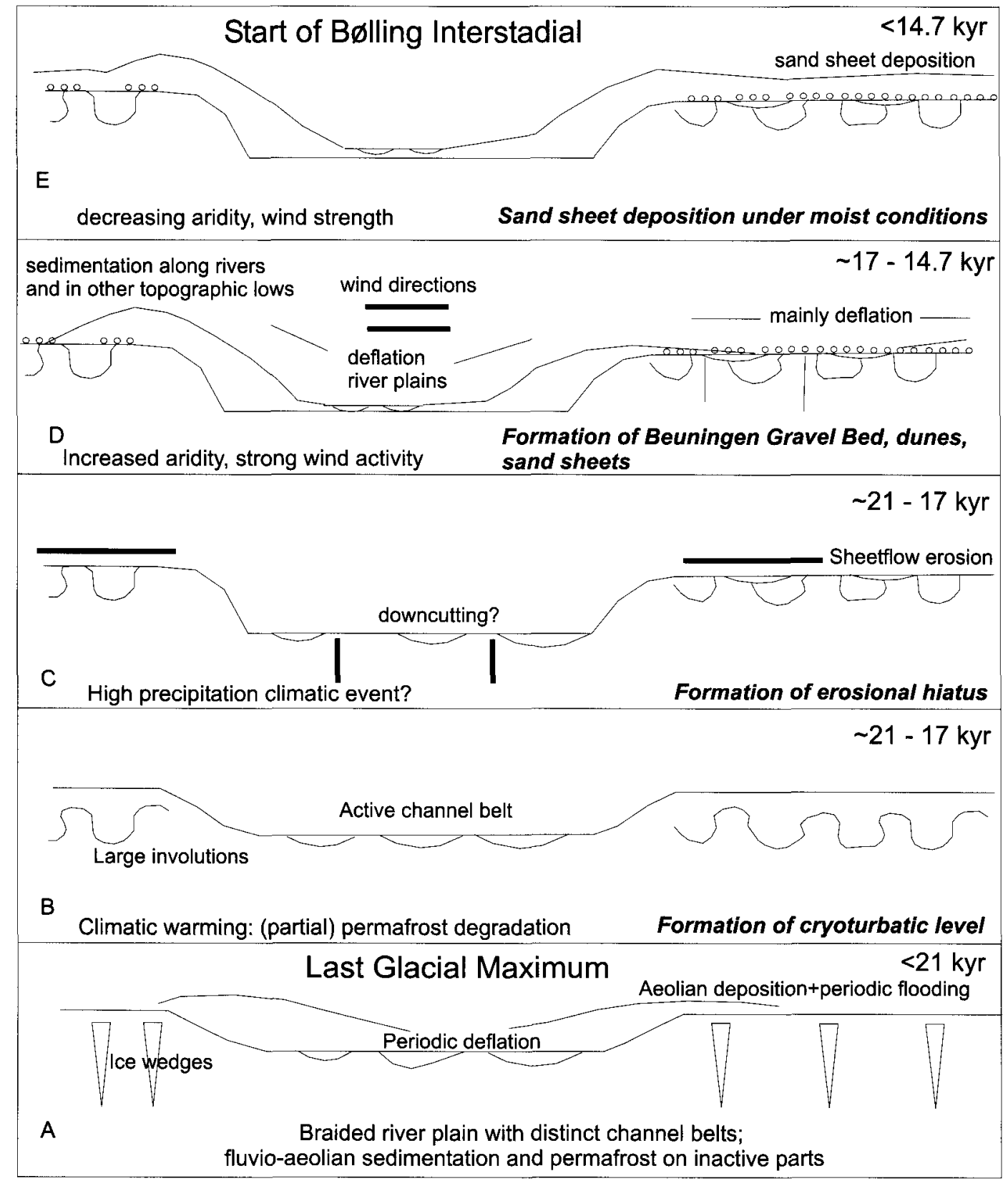

Fig. 12. Succession of aeolian, fluvial and cryogenic processes on the Dinkel river floodplain during the Weichselian Late Pleniglacial.

Late Pleniglacial fluvial deposits rarely contain organic matter in appreciable amounts and the palynological data point to an open vegetation (Kolstrup, 1980). Structures in the facies $D$ sands do not indicate a dense vegetation. Therefore, vegetation probably did not play a major role in the accumulation of the ridges. Aeolian sand accumulation on the higher side of a terrain step can be generated by wind velocity reduction in the vortex on the leeside of the terrain step if the wind is directed upslope (e.g. the cliff top dunes described by Pye \& Tsoar, 1990). This effect may have played a role at the Vrijdijk site. In the Lutterzand site the channel margin slope has been less steep (Fig. 5). High soil moisture promoting sand ac- cumulation may have occurred at the base of the channel margin slopes (due to seepage and river water) and the flat terrace surface beyond the terrain steps (due to imperfect drainage). Since abundant adhesion ripple lamination is found at the Lutterzand site, imperfect drainage is the most likely explanation for the ridge accumulation at that site.

Concluding, the combined effects of terrain steps and surface moisture distribution is the most likely cause of coversand ridge accumulation at the upslope side of the channel margin slopes. This requires transport of sand over the terrain steps in an upslope direction, which is confirmed by the sedimentary structures (see below). 
Variation of climate.

The permafrost degradation between 17 and $21 \mathrm{kyr}$ testifies of climatic warming after the Last Glacial Maximum. The ensuing surficial erosion and associated increased fluvial activity indicates that this coincided with a temporary increase of precipitation. In the aeolian deposits overlying the hiatus, no evidence is found of permafrost, indicating that the extreme cold conditions of the Glacial Maximum did not return. However, the intense aeolian activity, including widespread deflation, witnesses of relatively arid conditions (Kasse, 1997).

The sequence of sand sheet facies $C$ on facies $A$ indicates climatic change. Facies $\mathrm{A}$ contains frequent deflation levels, while adhesion lamination is absent. Furthermore, small frost fissures frequently occur in facies $\mathrm{A}$, accompanied by small scale cryoturbation; in facies $\mathrm{C}$ these features are absent. The frost fissures indicate mean annual temperatures below $0 \%$ (French, 1996; Huijzer \& Vandenberghe, 1998). Compared to facies $\mathrm{A}$, facies $\mathrm{C}$ shows rapid accumulation under warmer climatic conditions.

The age of the facies A sands can be bracketed between approximately $18 \mathrm{kyr}$ (based on the age of the underlying erosional hiatus) and the Bølling Interstadial, based on the dates of Bateman et al. (in prep.). During that time interval, the climate has been cold, with mean annual temperatures between $-4^{\circ}$ and $-7^{\circ}$ $\mathrm{C}$, based on the distribution of ice wedge casts in Europe (Huijzer \& Vandenberghe, 1998). The sedimentation of facies C occurred at the start of the Bølling Interstadial (see above). Also Kasse (1999) presents evidence of continued aeolian sedimentation and a slow stabilisation of the coversands by soils and vegetation during the Bølling Interstadial.

During deposition of facies $C$ the climate probably was not a limiting factor to the colonization of the coversand deposits by vegetation, since sedimentary structures indicate abundant moisture supply and absence of severe cold conditions. Still, any disturbances of the sedimentary structures or organic remains indicating a densely vegetated surface are lacking. Other factors than climate should have been operative, preventing colonization of the surface by plants during an already warming climate. The most likely factor is the nutrient-poor condition of the coversand deposits. The bare coversand surface should have been almost devoid of plant nutrients, which can be added to the soil only after colonization by nitrogen fixing plants and bacteria (Van Geel et al., 1989; Hoek \& Bohncke, 1997). Thus slow colonization by vegetation may have left sufficient sand source areas for continued coversand transport and accumulation, even when the climatic amelioration of the Late Glacial was in full swing. Especially the dry dune ridges along the valley margins may have provided a source area for the sand sheet of facies $C$, as shown by intercalation of the topmost facies D sands with facies C in Fig. 5.

\section{Palaeowind directions.}

The information on the Late Pleniglacial palaeowind directions derived from the coversands (table 4) indicate a strong, probably seasonal variability of the wind regime.

The east-west fining of the grainsize at the Vrijdijk site indicates palaeo-wind directions with a clear eastern component, which is in marked contrast with wind directions derived from the Lutterzand section based on location of the coversand ridges. The coarse sediment of the Vrijdijk ridge (and also the ridge on site 3 indicated in Fig. 1 and 3) implies that the easterly sand transporting winds were the most vigorous. A coarser aeolian sediment also may be induced by low air temperatures. Because of the higher air density, cold air is more effective in transporting coarse material (McKenna Neumann, 1993). The wind regime of the Late Pleniglacial between ca. 21 and 14 kyr can be summarized as 1) Generally westerly sand

Table 4. Indications for palaeowind directions in the Dinkel valley coversands of the Late Pleniglacial.

\begin{tabular}{|c|c|c|}
\hline Site & Sand-transporting palaeowind direction & Indicator \\
\hline Lutterzand section; Dinkel valley in general & From west & $\begin{array}{l}\text { Presence of coversand ridges on } \\
\text { (north)eastern valley sides }\end{array}$ \\
\hline Lutterzand section & From north to southwest (facies C) & $\begin{array}{l}\text { Attitudes of adhesion ripple } \\
\text { pseudo cross-lamination }\end{array}$ \\
\hline Dinkel valley (site 3, Vrijdijk dune ridge) & From north to east & $\begin{array}{l}\text { Presence of coarse-grained } \\
\text { coversand ridge to southwest and } \\
\text { west of former channel belt }\end{array}$ \\
\hline Vrijdijk dune ridge & From northeast to east & $\begin{array}{l}\text { Grainsize trend along flowpath } \\
\text { of wind }\end{array}$ \\
\hline
\end{tabular}


transporting wind directions in summer and winter; 2) Frequent easterly sand transporting winds in winter. Evidence for easterly wind directions during deposition of facies $\mathrm{C}$ at the start of the Bølling interstadial is absent.

Christiansen \& Svensson $(1998,1999)$ deduced a predominantly easterly wind direction from windpolished boulders in Denmark. Our data suggest that strong easterly winds occasionally may have occurred also in the Netherlands during the Late Pleniglacial next to a prevailing westerly wind direction. The eastern wind component may have been driven by the anticyclonic wind system over the Scandinavian ice cap (Meyer \& Kottmeyer, 1989; Vandenberghe et al., 1999). Based on the areal distribution pattern of loess and coversands in northwestern Europe, Schwan (1986) and Huijzer \& Vandenberghe (1998) assumed wind directions from the northern quadrant for the Late Pleniglacial. This general pattern of net northsouth transport points to an additional northern component, probably the resultant of northwesterly and northeasterly wind directions and the location of the source area, the dry North Sea basin.

To account for the data of table 4 , three scale orders of the process of aeolian particle transport must be considered. Firstly, there is a net, long-term north to south transport of sand and dust on a continental scale, determined by both source area and prevailing wind directions. The second order process involves a more limited areal context, e.g. the northern European lowland. Here, during all of the year, prevailing westerly winds carry particles to their depositional sites. In winter, aeolian sand transport is added to by strong easterly winds. In the third place the local pattern of aeolian deposition is controlled by the topography of the receiving site, i.e. by the topography of the Dinkel floodplain, and also by the short-term directional fluctuations of high winds.

\section{Conclusions.}

In the study area four facies of aeolian sand and/or silt were identified. Facies A has a relatively coarse texture and contains deflation levels. Both of these features suggest grain transport at high wind speed. Scours formed by current flow are present. Discontinuous involutions and numerous frost fissures relate to low winter temperatures.Facies B is of rare occurrence. It consists of well-sorted sand laid down by fluvial reworking of windborne sand. Facies $C$ is a sheetlike sand body with horizontal bedding and ample evidence of aeolian deposition on a damp or wet surface. Laminae of coarser and finer texture tend to alternate and may result from seasonal variation in wind strength. Syngenetic cryogenic structures are absent in the subject facies.Facies D supposedly represents a deposit of incipient dome dunes in which slip faces are absent. Although it formed in an environment, which was distinctly drier than that of facies $\mathrm{C}$, the soil-water regime permitted some growth of vegetation. Facies $D$ accumulations closest to the ancient channel belt suffered frequent reworking by flood-waters.

The succession of Late Pleniglacial events in the study area is as follows:

a) Fluvial deposition by a braided-river system and buildup of permafrost during the Last Glacial Maximum; b) Permafrost degradation and formation of large cryogenic involutions; c) Planation by surface runoff; d) Formation of a desert pavement (=Beuningen Gravel Bed). The establishment of this extensive deflation surface has been partly contemporaneous with the deposition of coversand.

The morphology of the Late Pleniglacial coversand-landscape in the Dinkel valley was controlled by the relief of the pre-existing floodplain. The slopes bordering the floodplain acted as topographical barriers which caused the wind to slow down and drop its load. As a result, coversand ridges accumulated with preference near the margins of the active channel belt. The ridges consist of low, rather flat dunes. Relatively thick sand sheets occur in their leesides. Thin sand sheets, alternating with deflation surfaces, are found at greater distance from the ridges.

Palaeowind data from the study area suggest aeolian particle transport from both westerly and easterly directions. To account for this feature, three orders of magnitude of the process of aeolian particle transport must be considered. Firstly, there is a net, long-term north to south transport of sand and dust on a continental scale. The second order process involves a more limited areal context, e.g. the northern European lowland. Here, during all of the year, mainly westerly winds carry particles to their depositional sites. In winter, aeolian sand transport is added to by frequent easterly winds of generally great strength. In the third place the local pattern of aeolian deposition will be controlled by the topography of the receiving site, i.e. by the topography of the Dinkel floodplain, and also by the short-term directional fluctuations of high winds.

Our data confirm previous observations that coversand deposition, including sand sheet formation, continued during the early part of the Bølling Interstadial. We suggest that nutrient-poor conditions of the coversand surface may have retarded colonization by vegetation, although other depositional features of the coversand indicate climatic amelioration. 


\section{Acknowledgements.}

We are indebted to Elsbeth Heijna and Edwin van Espelo for their contribution during the fieldwork in the Twente area. Martin Konert and his laboratory personnel are thanked for performing the grainsize analysis. We thank Dr. R.F.B. Isarin and Dr. M.E. Donselaar for their constructive reviews.

\section{References.}

Bateman, M.D. \& Van Huissteden, J., 1999. The timing of last glacial periglacial and aeolian events, Twente, eastern Netherlands. Journal of Quaternary Science 14: 277-283.

Bateman, M.D., Van Huissteden, J. \& Kasse, C. in prep. Chronology of cryostratigraphy and aeolian sedimentation during the Last Glacial termination in the Netherlands.

Björck S., Walker, M.J.C., Cwynar, L.C., Johnsen, S., Knudsen, K.-L, Lowe, J.J., Wohlfart, B., INTIMATE members, 1998. An event stratigraphy for the Last Termination in the North Atlantic region based on the Greenland ice-core record: A proposal by the INTIMATE group. Journal of Quaternary Science 13: 283292.

Catt, J.A., 1977. Loess and coversands. In: Shotton, F.W. (ed.): British Quaternary studies: recent advances. Oxford University Press (Oxford): 221-229.

Christiansen, H.H. \& Svensson, H., 1998. Windpolished boulders as indicators of a Late Weichselian wind regime in Denmark in relation to neighbouring areas. Permafrost and Periglacial Processes 9: 1-21.

Christiansen, H.H. \& Svensson, H., 1999. Windpolish evidence: an important direct indicator of geomorphologically active palaeowinds. A reply to the discussion by Vandenberghe, Isarin and Renssen. Permafrost and Periglacial Processes 10: 203-204.

Dijkmans, J. \& Törnqvist, T., 1991. Modern periglacial aeolian deposits and landforms in the Søndre Strømfjord area, West Greenland and their palaeoenvironmental implications. Meddedelser om Grønland, Geoscience 25: $39 \mathrm{pp}$.

Dijkmans, J.A.A. \& Wintle, A.G., 1991. Methodological problems in thermoluminescence dating of Weichselian coversand and late Holocene drift sand from the Lutterzand area, E. Netherlands. Geologie en Mijnbouw 70: 21-33.

Doppert, J.W.C., Ruegg, G.H.J., Van Staalduinen, C.J., Zagwijn, W.H. \& Zandstra, J.G., 1975. Formaties van het Kwartair en Boven Tertiair in Nederland. In: Zagwijn, W.H. \& Staalduinen, C.J. (eds.): Toelichting bij geologische overzichtskaarten van Nederland. Rijks Geologische Dienst (Haarlem):11-56.

French, H.M., 1996. The periglacial environment. Longman (London): $341 \mathrm{pp}$.

Good, T.R. \& Bryant I.D., 1985. Fluvio-aeolian sedimentation- An example from Banks Islands N.W.T., Canada. Geografiska Annaler $67 \mathrm{~A}: 33-46$.

Hoek, W. \& Bohncke, S.J.P., 1997. Environmental and climate changes in the Netherlands during the Lateglacial and Early Holocene. In: Hoek, W.: Palaeogeography of Lateglacial Vegetations. Aspects of Lateglacial and Early Holocene vegetation, abiotic landscape and climate in the Netherlands. Thesis, Vrije Universiteit (Amsterdam): 113-128.

Huijzer, B. \& Vandenberghe, J., 1998. Climatic reconstruction of the Weichselian Pleniglacial in northwestern and central Europe. Journal of Quaternary Science 13: 391-417.

Hunter, R.E., 1977. Basic types of stratification in small eolian dunes. Sedimentology 24: 361-387.
Kasse, C., 1997. Cold-climate aeolian sand-sheet formation in Northwestern Europe (c. 14-12.4 ka); a response to permafrost degradation and increased aridity. Permafrost and Periglacial Processes 8: 295-311.

Kasse, C., 1999. Late Pleniglacial and Late Glacial aeolian phases in the Netherlands. In: Schirmer, W. (ed.): Dunes and fossil soils. GeoArchaeoRhein 3: 61-82.

Kleinsman, W.B., De Lange, G.W., Maarleveld, G.C. \& Ten Cate, J.A.M., 1978. Geomorfologische kaart van Nederland 1:50.000 Blad 28 en blad 29 Almelo/Denekamp. Stichting voor Bodemkartering / Rijks Geologische Dienst (Wageningen/Haarlem).

Kocurek, G. \& Fielder, G., 1982. Adhesion structures. Journal of Sedimentary Petrology 52: 1229-1241.

Kolstrup, E., 1980. Climate and stratigraphy in Northwestern Europe between 30,000 B.P. and 20,000 B.P., with special reference to The Netherlands. Mededelingen van de Rijks Geologische Dienst 32-15: 181-253.

Koster, E.A., 1988. Ancient and modern cold-climate aeolian sand deposition: review. Journal of Quaternary Science 3: 69-83.

Kozarski, S. \& Nowaczyk, B., 1991. Lithofacies variation and chronostratigraphy of Late Vistulian and Holocene aeolian phenomena in northwestern Poland. Zeitschrift für Geomorphologie, Neue Folge, Suppl.-Band 90: 107-122.

Maarleveld, G.C., 1960. Wind directions and cover sands in the Netherlands. Biuletyn Peryglacjalny 8: 49-58.

Maarleveld, G.C., 1971. The geomorphological map of the Dinkel valley. In: Van der Hammen, T. \& Wijmstra, T.A. (eds.): The Upper Quaternary of the Dinkel valley. Mededelingen van de Rijks Geologische Dienst 22: 159-163.

Mol, J., Vandenberghe, J., Kasse, K. \& Stel, H., 1993. Periglacial microjointing and faulting in Weichselian fluvio-aeolian deposits. Journal of Quaternary Science 8: 15-30.

McKenna Neumann, C., 1993. A review of aeolian transport processes in cold environments. Progress in Physical Geography 17: 137-155.

Meyer, H.-H. \& Kottmeyer, C., 1989. Die atmosphärischen Zirkulation in Europa im Hochglazial der Weichsel-Eiszeit - abgeleitet von Paläowind-Indikatoren und Modellsimulationen. Eiszeitalter und Gegenwart 39: 10-18.

Pissart, A., Vincent, J.-S. \& Edlund, S.A., 1977. Dépôts et phénomènes éoliens sur l'île de Banks, Territoires du NordOuest, Canada. Canadian Journal of Earth Sciences 14: 24622480.

Pye, K. \& Tsoar, H., 1990. Aeolian sands and sand dunes. Unwin Hyman (London): 396 pp.

Romanovskii, N.N., 1985. Distribution of recently active ice and soil wedges in the USSR. In: M. Church, M. \& Slaymaker, O. (eds.). Field and Theory; lectures in geocryology. University of British Columbia Press (Vancouver): 154-165.

Ruegg, G.H.J., 1983. Periglacial eolian evenly laminated sandy deposits in the Late Pleistocene of NW Europe, a facies unrecorded in modern sedimentological handbooks. In: Brookfield, M.E. \& Ahlbrandt, T.S. (eds.): Eolian sediments and processes (Developments in Sedimentology 38). Elsevier (Amsterdam): 455-482.

Ruz, M.-H. \& Allard, M., 1995. Sedimentary structures of cold-climate coastal dunes, Eastern Hudson Bay, Canada. Sedimentology 42: 725-734.

Schwan. J., 1986. The origin of horizontal alternating bedding in Weichselian aeolian sands in Northwestern Europe. Sedimentary Geology 49: 73-108.

Schwan, J., 1987. Sedimentologic characteristics of a fluvial to aeolian succession in Weichselian Talsand in the Emsland (F.R.G.). Sedimentary Geology 52: 273-298.

Schwan, J., 1988. The structure and genesis of Weichselian to Early 
Holocene aeolian sand sheets in Western Europe. Sedimentary Geology 55: 197-232.

Schwan, J., 1989. Grain fabrics of natural and experimental lowangle aeolian sand deposits. Geologie en Mijnbouw 68: 211-219.

Vandenberghe, J., 1985. Paleoenvironment and stratigraphy during the last Glacial in the Belgian-Dutch border region. Quaternary Research 24: 23-38.

Vandenberghe, J., 1988. Cryoturbations. In: Clark, M.J. (ed.): Advances in Periglacial Geomorphology. Wiley (Chichester):179198.

Vandenberghe, J. \& Van Huissteden, J., 1988. Fluvio-aeolian interaction in a region of continuous permafrost. Proceedings 5 th International Conference on Permafrost. Tapir Publications (Trondheim): 876-881.

Vandenberghe, J., \& Kasse, C. 1993: Cryopedimentation on softsediment subsoils. Würburger Geographische Arbeiten 87: 283297.

Vandenberghe, J., Isarin, R.F.B. \& Renssen, H., 1999. Comments on Windpolished boulders as indicators of a Late Weichselian wind regime in Denmark in relation to neighbouring areas by Christiansen and Svensson [9(1): 1-21, 1998]. Permafrost and Periglacial Processes 10: 199-201.

Van der Hammen, T., 1951. Late Glacial flora and periglacial phenomena in the Netherlands. Thesis, Leiden University (Leiden): $183 \mathrm{pp}$.
Van der Hammen, T., 1971. The Upper Quaternary stratigraphy of the Dinkel valley. In: Van der Hammen, T. \& Wijmstra, T.A. (eds.): The Upper Quaternary of the Dinkel valley. Mededelingen van de Rijks Geologische Dienst 22: 81-85.

Van der Hammen, T. \& Wijmstra, T.A., 1971. The Upper Quaternary of the Dinkel valley. Mededelingen van de Rijks Geologische Dienst 22: 55-214.

Van Geel, B., Coope, G.R. \& Van der Hammen, T., 1989. Palaeoecology and stratigraphy of the Lateglacial type section at Usselo (The Netherlands). Review of Palaeobotany and Palynology 60: 25-130.

Van Huissteden, J., 1990. Tundra rivers of the last glacial: Sedimentation and geomorphological processes during the Middle Pleniglacial in Twente, Eastern Netherlands. Mededelingen Rijks Geologische Dienst 44: 3-138.

Van Huissteden, J., Vandenberghe, J., Van der Hammen, T. \& Laan, W., 2000. Fluvial and aeolian interaction under permafrost conditions: Weichselian Late Pleniglacial, Twente, eastern Netherlands. Catena 40: 307-321.

Vink, A.P.A. \& Sevink, J., 1971. Soils and paleosoils in the Lutterzand. In: Van der Hammen, T. \& Wijmstra, T.A. (eds.): The Upper Quaternary of the Dinkel valley. Mededelingen Rijks Geologische Dienst 22: 165-186.

Washburn, A.L., 1979. Geocryology. Edward Arnold (London): $406 \mathrm{pp}$. 